\title{
UTILIZATION OF MUNG BEAN (VIGNA RADIATE, LINNAEUS) AS A PROTEIN SOURCE IN EXPERIMENTAL DIETS FOR FRY NILE TILAPIA (OREOCHROMIS NILOTICUS): EFFECTS ON GROWTH PERFORMANCE, FEED UTILIZATION AND APPARENT DIGESTIBILITY CO-EFFICIENCY
}

\author{
M.A.M. Soliman', A.M. Batran' ${ }^{2}$ H.A.M. Soliman ${ }^{3}$ and S.A.A. Gomha ${ }^{2}$. \\ ${ }^{1}$ Utilization By-Products Department, Animal Production Research Institute (APRI), Agriculture \\ Research Center, Ministry of Agriculture, Dokky-Giza-Egypt. \\ ${ }^{2}$ Central Lab. of Aquaculture Research (CLAR), Agriculture Research Center (ARC), Egypt \\ ${ }^{3}$ Zoology Dept., Faculty of Science, Sohag Univ., Egypt
}

(Received 3/7 /2018, accepted 21/8/2018)

\section{SUMMARY}

\begin{abstract}
Seven experimental diets (30\% crude protein and $402.48 \pm 1.44 \mathrm{kcal} / 100 \mathrm{~g} \mathrm{GE}$ ) were formulated to replace $0.0,15,30,45,60,75$ and $100 \%$ of soybean meal protein (SBM) as plant protein source by mung bean seed (MBS). Nile tilapia fry with an average initial weight $(0.5 \pm 0.09 \mathrm{~g} / \mathrm{fish})$ were stocked at a rate of 15 fry/fiber glass tank ( 7 experimental diets $\mathrm{x} 3$ replicates (21 fiber glass tanks)) and fed with those diets for 14 weeks to evaluate the growth performance, feed utilization and apparent digestibility co-efficient under the indoor conditions. Results showed significant decrease $(\mathrm{P}<0.05)$ in growth performance with increasing level of MBS up to $15 \%$. The highest values of dry matter, protein, fat and energy intakes were recorded by the control and $15 \%$ MBS group with significant differences $(\mathrm{P}<0.05)$ compared with the other treatments groups. On the other hand, significant differences $(\mathrm{P}<0.05)$ among groups for $\mathrm{ADC} \%$ of $\mathrm{CP}, \mathrm{EE}, \mathrm{NFE}, \mathrm{DM}$ and energy were observed with increasing rate of MBS more than $15 \%$. There are significantly differences $(\mathrm{P}<0.05)$ for $\mathrm{FCR}$, but contrary no significant differences for FER among all the groups. Apparently, there were no effect for all levels of MBS on chemical compassion (CP, DM, EE, GE and HSI) and survival rate. Incorporation of raw MBS more than $15 \%$ affected adversely on growth performance, feed utilization and ADC\%. This may be due to anti-nutritional factors contents of MBS.
\end{abstract}

Keyword: Mung bean seed, soybean meal, Nile tilapia, growth performance, apparent digestibility.

\section{INTRODUCTION}

Fish feed represent almost 65 to $70 \%$ of the fish culture inputs, many attempts have been done to reduce the feed costs by using cheaper alternative sources of protein and/or energy of that so called nontraditional ingredients or by- products, which may have great values in producing cheap fish diets (Abd El-Hakim et al., 2003). Protein remains the most expensive ingredient in prepared feeds for most cultured organism, yet it is also the most important factor affecting growth performance of fish. Therefore, one of the foreseen constraints to intensification of fish farming is the scarcity of inexpensive, readily available and nutritive sources of protein (James et al., 2015). Soybean meal (SBM) is the most important nutritious of all plant protein sources (Lovell, 1988). Because of its high protein content, high digestibility, relatively well-balanced amino acid profile and steady supply, SBM is widely used as a cost-effective feed ingredient for many aquaculture animals (Storebakken et al., 2000); it is currently the most commonly used plant protein source in fish feeds (El-Sayed, 1999). The use of soybean meal as an alternative protein source became so expensive. So, it becomes a demand to look for another alternative protein source that could be used to partially or totally replace soybean meal without competing with 
human demand and locally available protein sources (Mohammed, 2008). The high cost and fluctuating quality of fish meal and soybean meal as well as uncertain availability (Alcerte, 2000), have led to the need to identify alternative protein sources for fish. Considerable emphasis has been focused on the use of conventional plant protein sources, such as mallow (Abd El-Hamid et al., 2004), and water hyacinth (Abd El-Hamid et al., 2006). Leguminous plants such as mung bean, (Vigna radiate, Linneaus) (De Silva and Anderson, 1995) and African Yam beans have been identified to be suitable protein sources for fish diets (Olaifia and Bello, 2011). Mung bean is a drought-resistant plant and is cultivated in many tropical countries. It contains high levels of protein and energy and has a good amino acid profile comparable to soybean, kidney pea meal, and to an FAO/WHO reference protein (El-Adawy, 1996). Also, mung beans play an important role in nutrition because they are rich source of nutrients with $23.7 \%$ crude protein (CP), crude fat (CF) of $1.9 \%$, certain amount of minerals and vitamins and essential amino acids which are comparable with that of soybean and kidney beans (Deshpande et al., 1982 and Habibullah and Shah, 2007). So, green mung bean was used to replace for fish meal in Asian sea bass (Eusebio and Coloso, 2000) and milkfish diets (Apines-Amar et al., 2015) without deleterious effects on growth of the fish. Mung bean seed (MBS) is an excellent source of high quality protein, cheapest and richest sources of plant protein which is commonly used in many products, ground mung bean may be used as a substitute or in combination with other ingredients in many food products (Kenawi et al, 2009). Also, Kataria et al. (1989) reported that some promising strains of amphidiploids (black gram x Mung bean) have been developed by Haryana Agricultural University, Hisar (India).The nutritive value of mixed rations depends on the nutrient composition of the individual feed components and the ability of the animal to digest and absorb the nutrients (Kirchgessner et al., 1986). No many studies so far done to evaluate the efficiency of MBS as feedstuffs. Such information is of paramount importance in the assessment of the economical use of this macro-phyte plant in aquaculture (Rahman-Tibin et al., 2012). Digestibility of feedstuff by the animal depends not only on the animal digestive tract architecture, physiology and environmental conditions, but also on it physical and nutrient characteristics (Lee and Lawrence, 1985; Akiyama et al., 1989).

This work aimed to evaluate the replacement of soybean meal protein by raw MBS on growth performance, feed utilization of Nile tilapia fry and apparent digestibility of dry matter, crude protein, ether extract, ash, NFE, energy and crude fibre.

\section{MATERIALS AND METHODS}

\section{First study: Feeding trial design}

An experimental attempt was carried out for 14 weeks (Dept. of Fish Nutrition, Central Lab. for Aquaculture Research (CLAR), Abbassa, Abou Hammad, Sharkia, Egypt) and aimed to investigate the effects of replacement of soybean meal (SBM) with raw MBS -as a main dietary plant protein source- on growth performance, feed utilization efficiency and digestibility of nutrients for male Nile tilapia $(O$. niloticus) fry. Twenty-one circular fiberglass tanks (50x40x35 cm with 50 liters in volume) were filled with de-chlorinated tap water and supplied with compressed air. Proximate analysis and essential amino acid profile of SBM and MBS used in the experimental are shown in Table (1). Seven experimental diets were formulated as following; the first (control) was formulated to contain soybean meal as the only main dietary plant protein source; the other six experimental diets were formulated to replace the raw MBS as plant protein at rate of $15,30,45,60,75$ and $100 \%$ instead of the soybean meal protein (Tables $2 \& 3)$. Male Nile tilapia fry $($ O. niloticus $)$ with an average initial weight $(0.5 \pm 0.09 \mathrm{~g} / \mathrm{fish})$ were obtained from tilapia hatchery of CLAR. The fish were transported and adapted for the wet Lab. conditions. Fish were classed to seven groups (with three replicates per each) and stocked at a rate of 15 fry/fiber glass tank. The diets were applied four times daily except Friday (9:00, 11:00, 13:00, and finally 15:00) to the fish at a rate of $10 \%$ of the fish biomass/day for six weeks then reduced to $5 \%$ for the rest time. All fish were weighed biweekly and the amount of the offered feed was readjusted accordingly. One third of water volume was changed daily but the whole water volume was totally changed weekly. 


\section{The proximate chemical analysis of diets and fish:}

At the beginning of the experiment, randomized samples of the tested diets and whole-fish body (5 fish) from each treatment were analysed according to the standard methods of AOAC (1990) for moisture, protein, fat, and ash.

Table (1): Proximate analysis and essential amino acid profile of SBM and MBS used in the experimental diets (\%; on DM basis) as cited from EI Sherbiny (2008)

\begin{tabular}{lcclcc}
\hline & \multicolumn{2}{c}{ Proximate analysis } & & \multicolumn{2}{c}{ *EAA } \\
\cline { 3 - 5 } Item & SBM & MBS & Item & SBM & MBS \\
\hline DM & 91.50 & 89.02 & Arginine & 4.07 & 1.24 \\
CP & 44 & 25.40 & Histidine & 1.35 & 0.77 \\
EE & 1.43 & 0.82 & Isoleucine & 2.73 & 1.24 \\
CF & 7.50 & 4.89 & Leusine & 4.14 & 2.23 \\
Ash & 7.27 & 3.60 & Lysine & 3.52 & 1.99 \\
**NFE & 39.80 & 65.29 & Methionine & 0.79 & 0.24 \\
${ }^{1}$ Total P & 0.70 & 0.50 & Cystine & 0.83 & 0.10 \\
${ }^{2}$ AV. P & 0.27 & 0.35 & Phenylalanine & 2.71 & 1.44 \\
GE ${ }^{3}$ (kcal/kg) & 4751 & 4438 & Tyrosine & 1.86 & 0.62 \\
& & & Threonine & 2.15 & 0.75 \\
& & & Tryptophan & 0.77 & 1.14 \\
\hline
\end{tabular}

*EAA= essential amino acids.

**NFE, nitrogen free extract $=100-(C P \%+C F \%+E E \%+A s h \%) .{ }^{1}$ Total $P$, total phosphorus. ${ }^{2} A V . P$, Available phosphorus $=$ Total phosphorus \% - phytate phosphorus \% according to (Wheeler and Ferrel, 1971).

${ }^{3} G E$, gross energy content was determined using bomb calorimeter according to (AOAC, 2005).

Table (2): Ingredients portions of the experimental diets in the experiment.

\begin{tabular}{|c|c|c|c|c|c|c|c|}
\hline \multirow[t]{2}{*}{ Ingredient } & \multicolumn{7}{|c|}{ Tested diets (mung bean levels \%) } \\
\hline & Control & $15 \%$ & $30 \%$ & $45 \%$ & $60 \%$ & $75 \%$ & $100 \%$ \\
\hline Fish meal & 16 & 16 & 16 & 16 & 16 & 16 & 16.5 \\
\hline Soybean meal & 30 & 27 & 23.2 & 21 & 18.3 & 12.8 & ----- \\
\hline MBS & ---- & 5 & 11 & 16.6 & 22.6 & 35.2 & 62 \\
\hline Yellow corn & 20 & 20 & 20 & 20 & 18 & 15 & 3.5 \\
\hline Wheat bran & 23 & 23 & 23 & 20 & 19 & 16 & 13 \\
\hline Cellulose & 2 & 2 & 1.2 & 1.2 & 1.2 & 1.00 & 1.00 \\
\hline Corn oil & 5 & 3 & 3 & 2.6 & 2.3 & 1.6 & 1.6 \\
\hline $\begin{array}{l}\text { Vit. }{ }^{1} \& \text { min. } .^{2} \\
\text { Premix }\end{array}$ & 2.00 & 2.00 & 1.4 & 1.4 & 1.4 & 1.4 & 1.4 \\
\hline Starch & 2 & 2 & 1.2 & 1.2 & 1.2 & 1.00 & 1.00 \\
\hline \multicolumn{8}{|c|}{$\begin{array}{l}{ }^{I} \text { Vitamin premix (per } \mathrm{kg} \text { of premix): thiamine. } 2.5 \mathrm{~g} ; \text { riboflavin, } 2.5 \mathrm{~g} ; \text { pyridoxine, } 2.0 \mathrm{~g} ; \text { inositol, } 100.0 \mathrm{~g} ; \text { biotin, } 0.3 \\
\mathrm{~g} ; \text { pantothenic acid, } 100.0 \mathrm{~g} ; \text { folic acid, } 0.75 \mathrm{~g} ; \text { para-aminobenzoic acid, } 2.5 \mathrm{~g} ; \text { choline, } 200.0 \mathrm{~g} ; \text { nicotinic acid, } 10.0 \\
\mathrm{~g} ; \text { cyanocobalamine, } 0.005 \mathrm{~g} ; \text { a-tocopherol acetate, } 20.1 \mathrm{~g} ; \text { menadione, } 2.0 \mathrm{~g} ; \text { retinol palmitate, } 100.000 \mathrm{IU} \text {; } \\
\text { cholecalciferiol, } 500.000 \mathrm{IU} .\end{array}$} \\
\hline \multicolumn{8}{|c|}{$\begin{array}{l}{ }^{2} \text { Minerals premix }\left(\mathrm{g} / \mathrm{kg} \text { of premix): } \mathrm{CaHPO}_{4} .2 \mathrm{H}_{2} \mathrm{O}, 727.2 ; \mathrm{MgCO}_{4} \cdot 7 \mathrm{H}_{2} \mathrm{O}, 127.5 ; \mathrm{KCl}, 50.0 ; \mathrm{NaCl}, 60.0 \text {; }\right. \\
\mathrm{FeC}_{6} \mathrm{H}_{5} \mathrm{O}_{7} .3 \mathrm{H}_{2} \mathrm{O}, 25.0 ; \mathrm{ZnCO}_{3}, 5.5 ; \mathrm{MnCl}_{2} .4 \mathrm{H}_{2} \mathrm{O}, 2.5 ; \mathrm{Cu}(\mathrm{OAc})_{2} \cdot \mathrm{H}_{2} \mathrm{O}, 0.785 ; \mathrm{CoCl}_{3} \cdot 6 \mathrm{H}_{2} \mathrm{O}, 0.477 ; \mathrm{CaIO}_{3} \cdot 6 \mathrm{H}_{2} \mathrm{O} \text {, } \\
\text { 0.295; } \mathrm{CrCl}_{3} .6 \mathrm{H}_{2} \mathrm{O}, 0.128 ; \mathrm{AlCl}_{3} .6 \mathrm{H}_{2} \mathrm{O}, 0.54 ; \mathrm{Na}_{2} \mathrm{SeO}_{3}, 0.03 .\end{array}$} \\
\hline
\end{tabular}


Table (3): Proximate analysis (on dry matter basis \%) of the experimental diets.

\begin{tabular}{lccccccc}
\hline Item & \multicolumn{5}{c}{ Tested diets (mung bean levels \%) } \\
\cline { 2 - 7 } & Control & 15 & 30 & 45 & 60 & 75 & 100 \\
\hline DM & 89.97 & 89.93 & 90.80 & 91.03 & 91.57 & 91.1 & 90.77 \\
CP & 30.21 & 30.18 & 30.01 & 30.08 & 30.03 & 30.06 & 30.04 \\
EE & 7.8 & 7.09 & 6.68 & 5.90 & 6.59 & 6.30 & 6.39 \\
Ash & 8.5 & 7.98 & 8.07 & 8.67 & 7.94 & 8.06 & 7.10 \\
CF & 6.07 & 5.97 & 6.53 & 6.38 & 6.48 & 6.20 & 6.83 \\
NFE & 47.42 & 48.78 & 48.71 & 48.97 & 48.96 & 49.38 & 49.64 \\
GE $^{4}$ (kcal/ 100 g diet) & 406.51 & 397.34 & 404.49 & 403.68 & 405.96 & 402.09 & 397.28 \\
\hline
\end{tabular}

${ }^{3}$ Nitrogen-free Extract $($ calculated by difference $)=100$ - (Protein + lipid + ash + fiber $) .{ }^{4}$ Gross energy (GE) was calculated from $(\mathrm{NRC}, 1993)$ as $5.65,9.45$, and $4.11 \mathrm{kcal} / \mathrm{g}$ factors for protein, lipid, and carbohydrates, respectively.

\section{- Growth and feed utilization parameters:}

Body weight gain (BWG); average daily gain (ADG); specific growth rate (SGR); feed conversion ratio (FCR); feed efficiency ratio (FER); protein, fat, and energy retention in fish body and finally survival rate (SR) were calculated according to the following equation:

1- Body weight gain $($ BWG; g/fish) $=\mathrm{W} 2-\mathrm{W} 1$.

2- Average daily weight gain $(\mathrm{ADWG} ; \mathrm{g} / \mathrm{fish} /$ day $)=(\mathrm{W} 2-\mathrm{W} 1) / \mathrm{T}$.

3- Specific growth rate $(\mathrm{SGR} ; \% /$ day $)=[100 \mathrm{x}(\mathrm{LnW} 2-\mathrm{LnW} 1)] / \mathrm{T}$.

Where: $\mathrm{W} 1=$ the initial weight $(\mathrm{g}), \mathrm{W} 2=$ the final weight $(\mathrm{g}), \mathrm{T}=$ the feeding period (days) and $\mathrm{Ln}=$ Natural $\log$.

4-Feed intake (FI; g /fish) = amount of feed intake (g/fish)/period.

5- Feed Conversion Ratio (FCR) = feed intake (on DM basis)/body weight gain

6- Feed Efficiency Ratio (FER) = [body weight gain (g)/(DM) feed intake (g)] x 100.

7- Hepatosomatic Indix (HIS; \%) = liver weight $(\mathrm{g}) /$ body weight $(\mathrm{g}) \times 100$.

8- Protein retention $(\mathrm{PR} ; \mathrm{g} / \mathrm{fish})=$ body protein at the end- body protein at the start.

9- Fat retention $(\mathrm{FR} ; \mathrm{g} / \mathrm{fish})=$ body fat at the end - body fat at the start.

10- Energy retention (ER; Kcal GE/fish) = body energy at the end - body energy at the start.

11 -Survival rate $(\%)=[$ No. of fish at the end of the study/ No. of fish at the start of the study $] \times 100$.

12- Dry matte intake $(\mathrm{DM} \mathrm{I}$; g/fish) = amount of consumed DM in feed (g/fish)/period.

13- Protein intake $(\mathrm{PI} ; \mathrm{g} / \mathrm{fish})=$ amount of consumed protein in feed $(\mathrm{g} / \mathrm{fish}) /$ period.

14- Fat intake (FI; g/fish) $=$ amount of consumed fat in feed $(\mathrm{g} /$ fish $) /$ period.

15- Energy intake $(\mathrm{EI} ; \mathrm{Kcal} / \mathrm{fish})=$ amount of consumed energy in feed (Kcal/fish)/period.

\section{The second study: Digestibility trial}

At the end of experimental period, a digestibility trial was carried out and the apparent digestibility coefficients of nutrients (ADC) were determined using ash or fibers as an internal marker according to Jones \& De Silva (1998) and Sales \& Janssens (2006). ADC \% of nutrients was calculated according to the following equation:

ADC $(\%)=100-[100 \times \%$ marker in feed $/ \%$ marker in feces $\times \%$ nutrient in feces/ $\%$ nutrient in feed].

Twenty-four fish from each treatment were allotted third aquaria (8 each repress ending replicated to carry out the digestibility trial. The fish were fed the experimental diets at a daily rate of $1 \%$ of aquarium 
fish biomass. The experimental diets were offered once daily at 11:00 am, after feces collection. Feces were collected by siphoning one time daily before feeding. Feces were kept in a deep freezer at $4^{\circ} \mathrm{C}$ after collection to avoid the fermentation according to the method of AOAC (1990). The digestion trial lasted 21 days.

\section{Statistical analysis:}

The data were statistically analyzed by analysis of variance using SPSS, 2001 (version 11.0) statistical software package (SPSS Inc., Prentice, Hall, USA). Analysis of variance (ANOVA) according to the following model: $Y_{i j}=\mu+A_{i}+e_{i j}$ Where: $Y_{i j}=$ The observation, $\mu=$ Overall mean, $A_{i}=$ Effect of rations and $\mathrm{e}_{\mathrm{ij}}=$ Experimental error. The Duncan's Post Hoc Multiply Comparisons test was performed to evaluate the difference among treatments means (Duncan, 1955).

\section{RESULTS AND DISCUSSION}

From the tables $(1,2 \& 3)$ it can be concluded that amino acids profile in the SBM was higher than that of MBS except the tryptophan acid (0.77) where it was higher in MBS (1.14). Also, SBM contained higher crude protein, ether extract, total phosphorus, crude fiber and gross energy as compared to those of MBS except available phosphorus where higher for MBS $(0.35 \%)$ than SBM $(0.27 \%)$ was observed. In general, both calculated and determined chemical composition of the experimental diets showed limited variations in nutrients contents among the different experimental diets.

\section{Growth performance:}

Results of the effect of replacing SBM by MBS on final body weight (FBW), average body weight gain (ABWG), specific growth rate (SGR) and survival rate (SR) of Nile tilapia fry are presented in Table (4). The initial fish weight ranged between 0.56 to $0.58 \mathrm{~g}$ with insignificant differences among the dietary treatments. No significant difference $(\mathrm{P}>0.05)$ was observed for FBW of fish that fed control and $15 \%$ MBS, but the FBW decreased significantly $(\mathrm{P}<0.05)$ with increase of MBS level. So, it can be concluded that the replacement of 30, 45, 60, 75 and $100 \%$ MBS depressed the FBW of Nile tilapia. Also, a same trend was observed for both relative BWG (g/fish) and ABWG (g/fish/day). While, the lowest daily weight gain (g/fish/day) was obtained from both 75 and $100 \%$ groups. Contrary, the values of SGR were affected significantly $(\mathrm{P}<0.05)$ at all treatments. The best SGR values were observed at both 15\% MBS (3.142) and control diet (3.140). The increase of replacement $\%$ of MBS, the decrease of survival rate\% (where the control, 15, 30, 45, 60, 75, and 100\% MBS were 70.5, 68.9, 67.3, 66.7, 64.9, 62.1 and $60.5 \%$, respectively) with no significant differences ( $\mathrm{P}>0.05)$ among treatments. To a great extent, a similar results were obtained by El Sherbiny (2008), where he found that the replacement of raw MBS at $25 \%$ of SBM protein had highly significant reduction $(\mathrm{P}<0.001)$ in FBW, BWG and SGR compared the control group, while, the lowest FBW was exhibited by the group fed 50\% raw MBS). In another study, Ahmed et al. (2009) reported that the FBW, BWG and SGR were decreased with the increase of black seed meal (Nigella sativa) (BSM) level in the tested diets. They attributed the reduction in FBW to the presence of various anti-nutrients. Adebayo et al. (2004) reported that the fish fed on 670 kg Cassia fistula seed meal (CFM) dietary inclusion had the lowest percentage survival rate, and may due mainly to the effect of fish handling. In the current study, the decreased values of growth parameters may be attributed to phytic acid, saponin and polyphenol contents in grains of various varieties of black gram (Vigna mungo) Mung bean (Vigna radiata L.) amphidiploids which ranged from 697 to 750, 2746 to 2972 and 702 to $783 \mathrm{mg} / 100 \mathrm{~g}$, respectively (Kataria et al., 1989). They, also, mentioned that domestic processing and cooking methods including soaking, ordinary and pressure-cooking of soaked and unsoaked seeds, and sprouting significantly lowered phytic acid, saponin and polyphenol contents of the amphidiploid seeds. They, also, indicated that anti-nutrient concentrations declined following sprouting; the longer the period of germination the greater was the reduction. 
Table (4): Effects of experimental diets (different levels of MBS) on the growth performance parameters of fry Nile tilapia $(O$. niloticus) reared under indoor conditions for 14 weeks study period.

\begin{tabular}{|c|c|c|c|c|c|c|}
\hline Item & $\begin{array}{l}\text { Initial weight } \\
\text { (g/fish) }\end{array}$ & $\begin{array}{c}\text { FBW } \\
\text { (g/fish) }\end{array}$ & $\begin{array}{l}\text { BWG } \\
\text { (g/fish) }\end{array}$ & $\begin{array}{c}\text { ADW G } \\
\text { (g/fish/day) }\end{array}$ & SGR (\%/day) & SR $(\%)$ \\
\hline \multirow{2}{*}{ Control } & 0.57 & $15.40^{\mathrm{a}}$ & $14.83^{\mathrm{a}}$ & $0.141^{\mathrm{a}}$ & $3.140^{\mathrm{ab}}$ & $70.5^{\mathrm{a}}$ \\
\hline & \pm 0.009 & \pm 1.47 & \pm 1.48 & \pm 0.015 & \pm 0.11 & \pm 2.23 \\
\hline \multirow{2}{*}{$15 \%$} & 0.58 & $15.98^{\mathrm{a}}$ & $15.39^{\mathrm{a}}$ & $0.147^{\mathrm{a}}$ & $3.142^{\mathrm{a}}$ & $68.9^{\mathrm{ab}}$ \\
\hline & \pm 0.003 & \pm 0.68 & \pm 0.68 & \pm 0.006 & \pm 0.05 & \pm 2.20 \\
\hline \multirow{2}{*}{$30 \%$} & 0.57 & $11.93^{\mathrm{b}}$ & $11.36^{\mathrm{b}}$ & $0.108^{b}$ & $2.896^{\mathrm{bc}}$ & $68.3^{\mathrm{ab}}$ \\
\hline & \pm 0.015 & \pm 0.80 & \pm 0.79 & \pm 0.008 & \pm 0.05 & \pm 3.83 \\
\hline \multirow{2}{*}{$45 \%$} & 0.58 & $11.93^{\mathrm{b}}$ & $11.35^{\mathrm{b}}$ & $0.108^{\mathrm{b}}$ & $2.880^{\mathrm{bc}}$ & $66.7^{\mathrm{b}}$ \\
\hline & \pm 0.007 & \pm 0.99 & \pm 0.99 & \pm 0.011 & \pm 0.08 & \pm 3.84 \\
\hline \multirow{2}{*}{$60 \%$} & 0.56 & $11.76^{\mathrm{b}}$ & $11.21^{\mathrm{b}}$ & $0.107 \mathrm{~b}$ & $2.917^{\mathrm{abc}}$ & $64.9^{\mathrm{bc}}$ \\
\hline & \pm 0.006 & \pm 0.52 & \pm 0.86 & \pm 0.009 & \pm 0.07 & \pm 4.43 \\
\hline \multirow{2}{*}{$75 \%$} & 0.57 & $11.71^{\mathrm{b}}$ & $11.14^{\mathrm{b}}$ & $0.106^{\mathrm{b}}$ & $2.879^{\mathrm{c}}$ & $62.1^{\mathrm{bc}}$ \\
\hline & \pm 0.009 & \pm 0.88 & \pm 1.05 & \pm 0.009 & \pm 0.09 & \pm 4.44 \\
\hline \multirow{2}{*}{$100 \%$} & 0.56 & $11.74^{\mathrm{b}}$ & $11.18^{\mathrm{b}}$ & $0.106^{\mathrm{b}}$ & $2.898^{b c}$ & $60.5^{c}$ \\
\hline & \pm 0.009 & \pm 0.45 & \pm 0.44 & \pm 0.004 & \pm 0.023 & \pm 0.00 \\
\hline
\end{tabular}

Means having the same letter in the same column are not significantly differed at $(P<0.05)$.

As shown in Table (5), results of feed intake (FI) indicated that control and 15\% MBS diets had a significant difference $(\mathrm{P}<0.05)$ with highest values $(37$ and 36.28 , respectively) than that of the rest treatments (the other levels of MBS), where they did not affected significantly $(\mathrm{P}>0.05)$. FCR values were affected negatively and significant differences $(\mathrm{P}<0.05)$ for both $15 \%$ and $100 \%$ MBS when compared with the other groups. The FER ranged from 39.83 (the lowest value for $75 \%$ MBS) to 45.12 (the highest value for $60 \%$ MBS) with no significant different among treatments. El Sherbiny (2008) replaced soybean meal protein by $25 \%$ and $50 \%$ raw MBS and found that a highly values in FCR compared with the control diet. Ahmed, et al. (2009) who reported that the FI was significantly decreased with increasing of BSM level $(\mathrm{P}<0.05)$ excepted diets containing up $20 \%$ black seed meal. Abd El-Hakim et al. (2008) reported that replacing $30 \%$ of soybean meal protein by rumen content or sunflower meal or sesame seed cake had no adverse effect on feed efficiency ratio (FER) of growing Nile tilapia. It can be summarized that there was a significant correlation between the fish weight gain and feed intake (FI; the ability of feed consumption) of the fish where they had, to a great extent, a similar trend.

Table (5): Effects of experimental diets (with different levels of MBS) on feed utilization of fry Nile tilapia $(O$. niloticus) reared under indoor conditions for 14 weeks study period.

\begin{tabular}{lcccc}
\hline Item & BWG (g/fish) & FI (g/fish) & FCR & FER \\
\hline \multirow{2}{*}{ Control } & $14.83^{\mathrm{a}}$ & $37.00^{\mathrm{a}}$ & $2.49^{\mathrm{a}}$ & $40.00^{\mathrm{a}}$ \\
& \pm 1.48 & \pm 2.84 & \pm 0.19 & \pm 2.20 \\
$15 \%$ & $15.39^{\mathrm{a}}$ & $36.28^{\mathrm{a}}$ & $2.36^{\mathrm{c}}$ & $41.63^{\mathrm{a}}$ \\
& \pm 0.68 & \pm 1.57 & \pm 0.07 & \pm 1.52 \\
$30 \%$ & $11.36^{\mathrm{b}}$ & $27.66^{\mathrm{b}}$ & $2.43^{\mathrm{b}}$ & $42.10^{\mathrm{a}}$ \\
& \pm 0.79 & \pm 2.53 & \pm 0.13 & \pm 2.17 \\
$45 \%$ & $11.35^{\mathrm{b}}$ & $26.67^{\mathrm{b}}$ & $2.36^{\mathrm{c}}$ & $41.65^{\mathrm{a}}$ \\
& \pm 0.99 & \pm 1.37 & \pm 0.12 & \pm 2.25 \\
$60 \%$ & $11.21^{\mathrm{b}}$ & $25.54^{\mathrm{b}}$ & $2.43^{\mathrm{b}}$ & $45.12^{\mathrm{a}}$ \\
& \pm 0.86 & \pm 0.91 & \pm 0.10 & \pm 4.25 \\
$75 \%$ & $11.14^{\mathrm{b}}$ & $27.05^{\mathrm{b}}$ & $2.45^{\mathrm{ab}}$ & $39.83^{\mathrm{a}}$ \\
& \pm 1.05 & \pm 0.89 & \pm 0.16 & \pm 1.87 \\
& $11.18 \mathrm{~b}$ & $26.28 \mathrm{~b}$ & $2.35 \mathrm{~b}$ & $43.27 \mathrm{a}$ \\
\hline
\end{tabular}

Means having the same letter in the same column are not significantly differed at $P>0.05$. 
As presented in Table (6), all the values of the dry matter (DM) intake, protein intake (g/fish), fat intake (g/fish) the energy intake (EI) (kcal/fish), not only, had a similar trend, but also, were affected significantly $(\mathrm{P}<0.05)$ where the control and $15 \%$ MBS had the high significant $(\mathrm{P}<0.05)$ one than that the other treatments. So, the increase of MBS levels the decrease the previous mentioned items. These results are agreement with the finding of Azaza et al. (2009) where are found that when the diets containing faba bean meal (FBM) content exceeded $24 \%$, the amount of dry matter, protein, fat and energy intake were decreased, Also, Sidduraju and Becker (2001) reported that the diets containing higher than $13 \%$ mucuna meal produced increased in amount of dry matter, protein, fat and energy intake. In general, all feed utilization parameters were decreased significantly by replacing the SBM by the MBS.

Table (6): Effects of experimental diets (with different levels of MBS) on the dry matter, protein, fat, and energy intake for fry Nile tilapia (O. niloticus) ) reared under indoor conditions for 14 weeks study period.

\begin{tabular}{lcccc}
\hline Item & $\begin{array}{c}\text { DM intake } \\
(\mathrm{g} / \text { fish })\end{array}$ & $\begin{array}{c}\text { Protein intake } \\
(\mathrm{g} / \text { fish })\end{array}$ & $\begin{array}{c}\text { Fat intake } \\
(\mathrm{g} / \text { fish })\end{array}$ & $\begin{array}{c}\text { Energy intake } \\
(\mathrm{kcal} / \text { fish })\end{array}$ \\
\hline \multirow{2}{*}{ Control } & $26.21^{\mathrm{a}}$ & $10.21^{\mathrm{a}}$ & $1.41^{\mathrm{a}}$ & $129.33^{\mathrm{a}}$ \\
& \pm 2.01 & \pm 0.89 & \pm 0.11 & \pm 10.15 \\
$15 \%$ & $25.33^{\mathrm{a}}$ & $9.90^{\mathrm{a}}$ & $1.36^{\mathrm{a}}$ & $125.39^{\mathrm{a}}$ \\
& \pm 1.08 & \pm 0.62 & \pm 0.05 & \pm 6.08 \\
$30 \%$ & $20.04^{\mathrm{b}}$ & $7.96^{\mathrm{b}}$ & $1.06^{\mathrm{b}}$ & $98.60^{\mathrm{b}}$ \\
& \pm 1.88 & \pm 0.99 & \pm 0.11 & \pm 9.21 \\
$45 \%$ & $19.17^{\mathrm{b}}$ & $7.42^{\mathrm{b}}$ & $1.01 \mathrm{~b}$ & $94.08^{\mathrm{b}}$ \\
& \pm 0.91 & \pm 0.38 & \pm 0.05 & \pm 4.65 \\
$60 \%$ & $18.48^{\mathrm{b}}$ & $7.15^{\mathrm{b}}$ & $0.98^{\mathrm{b}}$ & $90.39^{\mathrm{b}}$ \\
& \pm 0.63 & \pm 0.32 & \pm 0.04 & \pm 3.29 \\
$75 \%$ & $19.45^{\mathrm{b}}$ & $7.48^{\mathrm{b}}$ & $1.09^{\mathrm{b}}$ & $95.69^{\mathrm{b}}$ \\
& \pm 0.55 & \pm 0.32 & \pm 0.01 & \pm 3.046 \\
& $18.81^{\mathrm{b}}$ & $7.26^{\mathrm{b}}$ & $0.99^{\mathrm{b}}$ & $92.44^{\mathrm{b}}$ \\
\hline
\end{tabular}

Means having the same letter in the same column are not significantly differed at $P>0.05$.

Averages of protein, fat and energy content of whole-fish bodies at the start of the study were not significantly differences $(\mathrm{P}>0.05)$ among the treatments, but they differed significantly $(\mathrm{P}<0.05)$ at the end of the study except for protein content. The protein retention value did not affected significantly $(\mathrm{P}>0.05)$ with replacing of MBS, contrary, the protein retention $\%$ of was affected significantly $(\mathrm{P}<0.05)$. On the other hand, all retention values and their percentages for the rest parameters (fat and energy) were affected significantly $(\mathrm{P}<0.05)$ (Table 7). The $100 \%$ MBS group had the highest significant percent of protein retention $\%(160.85 \%)$, whereas the $30 \%$ MBS group had the highest significant percent of fat retention\% (101.59), and finally, the 15\% MBS group had the highest significant percent of energy retention\% (105.80) when compared with the control. This result agree with findings of El-Sherbiny (2008) who found that was a significant reduction in the protein, fat and energy retention in whole-fish bodies when fed the diets containing 25\% and 50\% raw MBS compared to the control diet. Also, Siddhuraju and Becker $(2001)$ recorded significant $(\mathrm{P}<0.05)$ reduction in total dietary protein and decreasing apparent net protein utilization and energy retention when common carp was fed more than $13 \%$ raw mucuna seed. The authors are attributed this depression in protein, fat and energy retention in the fish fed raw legume seeds to both limitations and change in the ratio between essential fatty acids. Limitation of essential fatty acids might have resulted from the presence of antinutritional factors. In this connection, Norton, (1991) explained the action of trypsin inhibitors on protein utilization, based on the hypothesis that, trypsin inhibitors block the receptors of the protuletic enzymes, where one molecule from trypsin inhibitors could block one or two molecules of chymotrypsin and one or two molecules of trypsin thus causing a break in the metabolic cycle of protein. This was reflected on the retained amount of protein in Nile tilapia body. 
Table (7): The retention of protein, fat and energy by fry Nile tilapia (O. niloticus) fed experimental diets (with different levels of MBS) for 14 weeks under indoor conditions.

\begin{tabular}{|c|c|c|c|c|c|c|c|c|c|c|c|c|}
\hline \multirow[b]{2}{*}{ Item } & \multicolumn{4}{|c|}{ Protein (g/fish) } & \multicolumn{4}{|c|}{ Fat (g/fish) } & \multicolumn{4}{|c|}{ Energy (Kcal GE/fish) } \\
\hline & Start & Final & Ret. & $\%$ & Start & Final & Ret. & $\%$ & Start & Final & Ret. & $\%$ \\
\hline \multirow[t]{2}{*}{ Control } & $56.40^{\mathrm{a}}$ & $52.83 a$ & $3.57^{\mathrm{a}}$ & $100.00^{\mathrm{bc}}$ & $14.83^{\mathrm{a}}$ & $28.23^{\mathrm{a}} \pm$ & $13.40^{\mathrm{a}}$ & $100.00^{\mathrm{a}}$ & $1.96^{\mathrm{a}}$ & $66.64^{\mathrm{ab}}$ & $64.68^{\mathrm{ab}}$ & $100.00^{\mathrm{a}}$ \\
\hline & \pm 1.15 & \pm 1.17 & \pm 0.82 & \pm 0.00 & \pm 0.19 & 0.45 & \pm 0.50 & \pm 0.00 & \pm 0.001 & \pm 7.44 & \pm 7.44 & \pm 0.00 \\
\hline \multirow[t]{2}{*}{$15 \%$} & $56.40^{\mathrm{a}}$ & $53.43 \mathrm{a}$ & $2.97^{\mathrm{a}}$ & $82.36^{\mathrm{c}}$ & $14.83^{\mathrm{a}}$ & $25.07^{\mathrm{c}}$ & $10.23^{\mathrm{c}}$ & $76.32^{\mathrm{c}}$ & $2.01^{\mathrm{a}}$ & $68.99^{\mathrm{a}}$ & $66.99^{a} \pm 3.06$ & $105.8^{\mathrm{a}}$ \\
\hline & \pm 1.15 & \pm 0.84 & \pm 0.86 & \pm 12.33 & \pm 0.19 & \pm 0.49 & \pm 0.49 & \pm 1.24 & \pm 0.001 & \pm 3.05 & & \pm 11.06 \\
\hline \multirow[t]{2}{*}{$30 \%$} & $56.40^{\mathrm{a}}$ & $52.20^{\mathrm{a}}$ & $4.20^{\mathrm{a}}$ & $131.17^{\mathrm{b}}$ & $14.83^{\mathrm{a}}$ & $28.43^{\mathrm{a}}$ & $13.60^{\mathrm{a}}$ & $101.59^{\mathrm{a}}$ & $1.96^{\mathrm{a}}$ & $53.75^{\mathrm{abc}}$ & $51.79^{\mathrm{abc}}$ & $83.63^{\mathrm{bc}}$ \\
\hline & \pm 1.15 & \pm 0.51 & \pm 0.92 & \pm 46.03 & \pm 0.19 & \pm 0.24 & \pm 0.38 & \pm 1.99 & \pm 0.008 & \pm 4.21 & \pm 4.16 & \pm 17.30 \\
\hline \multirow[t]{2}{*}{$45 \%$} & $56.40^{\mathrm{a}}$ & $53.10^{\mathrm{a}}$ & $3.77^{\mathrm{a}}$ & $110.61^{b c}$ & $14.83^{\mathrm{a}}$ & $19.33^{\mathrm{e}}$ & $4.50^{\mathrm{e}}$ & $33.52^{f}$ & $1.96^{\mathrm{a}}$ & $49.48^{c}$ & $47.52^{c} \pm 5.55$ & $77.89^{c}$ \\
\hline & \pm 1.15 & \pm 0.85 & \pm 1.53 & \pm 53.25 & \pm 0.19 & \pm 0.20 & \pm 0.36 & \pm 1.96 & \pm 0.001 & \pm 5.55 & & \pm 19.49 \\
\hline \multirow[t]{2}{*}{$60 \%$} & $56.40^{\mathrm{a}}$ & $51.33^{\mathrm{a}}$ & $5.07^{\mathrm{a}}$ & $165.3^{\mathrm{a}}$ & $14.83^{\mathrm{a}}$ & $23.07^{\mathrm{d}}$ & $8.23^{\mathrm{d}}$ & $61.65^{\mathrm{d}}$ & $1.91^{\mathrm{a}}$ & $50.94^{\mathrm{bc}}$ & $49.03^{\mathrm{bc}}$ & $79.43^{\mathrm{bc}}$ \\
\hline & \pm 1.15 & \pm 1.13 & \pm 1.22 & \pm 64.06 & \pm 0.19 & \pm 0.23 & \pm 0.34 & \pm 3.74 & \pm 0.047 & \pm 3.21 & \pm 3.26 & \pm 15.89 \\
\hline \multirow[t]{2}{*}{$75 \%$} & $56.40^{\mathrm{a}}$ & $51.57^{\mathrm{a}}$ & $4.83^{\mathrm{a}}$ & $154.49^{\mathrm{ab}}$ & $14.83^{\mathrm{a}}$ & $22.03^{\mathrm{d}}$ & $7.20^{\mathrm{d}}$ & $53.76^{\mathrm{e}}$ & $1.96^{\mathrm{a}}$ & $44.37^{\mathrm{c}}$ & $42.26^{\mathrm{c}} \pm 6.44$ & $66.07^{\mathrm{c}}$ \\
\hline & \pm 1.15 & \pm 0.80 & \pm 1.30 & \pm 63.34 & \pm 0.19 & \pm 0.53 & \pm 0.40 & \pm 2.71 & \pm 0.001 & \pm 6.36 & & \pm 8.48 \\
\hline \multirow[t]{2}{*}{$100 \%$} & $56.40^{\mathrm{a}}$ & $51.47^{\mathrm{a}}$ & $5.60^{\mathrm{a}}$ & $160.85^{\mathrm{a}}$ & $14.83^{\mathrm{a}}$ & $26.33^{\mathrm{b}}$ & $11.50^{\mathrm{b}}$ & $86.10^{\mathrm{b}}$ & $1.91^{\mathrm{a}}$ & $58.28^{\mathrm{abc}}$ & $56.37^{\mathrm{abc}}$ & $89.76^{\mathrm{ab}}$ \\
\hline & \pm 1.15 & \pm 1.84 & \pm 2.31 & \pm 73.32 & \pm 0.19 & \pm 0.39 & \pm 0.21 & \pm 3.98 & \pm 0.047 & \pm 2.38 & \pm 2.37 & \pm 11.77 \\
\hline
\end{tabular}

Means having the same letter in the same column are not significantly differed at $P>0.05$. 


\section{The effect of dietary treatment on the chemical composition and energy content of Nile tilapia:}

Averages dry matter content of final whole-fish body (DM \%) had no significant difference ( $\mathrm{P}>0.05)$ for all treatments (where the\% ranged from 23.36 to $24.43 \%$ ), but they were significantly higher $(\mathrm{P}<0.05)$ than initial one $(21.23 \%)$ (Table 8$)$. Regarding to crude protein $(\mathrm{CP} \%)$, there were slightly significant $(\mathrm{P}<0.05)$ differences among different treatments due to the inclusion of mung bean in fish diet. The Ether extract (EE \%) had the same trend of the DM \%. The ash contents \% at the study start recorded the highest significant $(\mathrm{P}<0.05)$ values $(28.26 \%)$ when compared with all treatments at the end of the study, which had a slightly changes with/without significant (they ranged from 22.56 to $26.47 \%$ ). It is clear that the hepato-somatic index (HSI \%) was not significant differences $(\mathrm{P}>0.05)$ among the groups. As presented in table (8), the gross energy contents (GE) in whole fish body (on DM basis) of the 15\% MBS group showed a highest significant $(\mathrm{P}<0.05)$ GE contents $(19.76)$ in their bodies when compared with the other groups. This result aggress with that of Azaza et al. (2009) who found that the carcass composition was not affected by diets composition, there was no differences in carcass protein, EE, ash content and HSI among the treatments. Also, Siddhuraju and Becker (2001) found that there was no significant difference in body protein, body lipid and ash content for fish fed the control diet and these fed raw mucuna bean seeds up to $13 \%(10 \%$ of total dietary protein) inclusion. Increasing the inclusion percentage of mucuna seed had significantly reduced body protein content and gross energy. Ahmed et al. (2009) reported that no significant differences in chemical composition of whole-fish bodies under the all treatment diets. In the same trend. El Sherbiny (2008) reported that the chemical composition of Nile tilapia body affected with increasing level of raw MBS in fish diet from 25\% to 50\% MBS compared to the control diet (SBM as protein source). According to (Liener, 1989; cited by Francis et al. 2001), that the antinutritional effect of tannins results from the interference with the digestive processes either by binding the enzymes or by binding to feed components like proteins or lipids. Mung bean content from non-starch polysaccharides was very low (0.41-2.5\%) as reported by Mubarak (2005) and Ramakrishna et al. (2006) compared to soybean grains (5-6\%).

Table (8): The chemical composition (\%; on DM basis) and energy contents of fry Nile tilapia $(O$. niloticus) carcass fed experimental diets (with different levels of MBS) for 14 weeks under indoor conditions.

\begin{tabular}{lcccccccc}
\hline \multirow{2}{*}{ Treatments } & \multirow{2}{*}{ Initial } & \multicolumn{7}{c}{ Final } \\
\cline { 3 - 9 } & & Control & $15 \%$ & $30 \%$ & $45 \%$ & $60 \%$ & $75 \%$ & $100 \%$ \\
\hline \multirow{2}{*}{ DM \% } & $21.23^{\mathrm{b}}$ & $23.74^{\mathrm{a}}$ & $23.36^{\mathrm{a}}$ & $24.26^{\mathrm{a}}$ & $24.35^{\mathrm{a}}$ & $24.07^{\mathrm{a}}$ & $23.76^{\mathrm{a}}$ & $24.43^{\mathrm{a}}$ \\
& \pm 0.62 & \pm 0.38 & \pm 0.17 & \pm 0.32 & \pm 0.74 & \pm 0.41 & \pm 0.43 & \pm 0.51 \\
$\mathrm{CP} \%$ & $55.69^{\mathrm{a}}$ & $52.88^{\mathrm{ab}}$ & $53.46^{\mathrm{ab}}$ & $52.23^{\mathrm{ab}}$ & $52.14^{\mathrm{ab}}$ & $51.31^{\mathrm{b}}$ & $51.61^{\mathrm{b}}$ & $51.21^{\mathrm{b}}$ \\
& \pm 0.38 & \pm 1.19 & \pm 0.83 & \pm 0.50 & \pm 0.86 & \pm 1.15 & \pm 0.80 & \pm 1.59 \\
$\mathrm{EE} \%$ & $14.29^{\mathrm{d}}$ & $22.26^{\mathrm{abc}}$ & $23.98^{\mathrm{a}}$ & $23.65^{\mathrm{ab}}$ & $20.39^{\mathrm{c}}$ & $23.09^{\mathrm{ab}}$ & $22.07^{\mathrm{bc}}$ & $23.26^{\mathrm{ab}}$ \\
& \pm 0.50 & \pm 0.70 & \pm 0.40 & \pm 1.28 & \pm 0.31 & \pm 0.25 & \pm 0.54 & \pm 0.22 \\
Ash \% & $28.26^{\mathrm{a}}$ & $24.85^{\mathrm{ab}}$ & $22.56^{\mathrm{b}}$ & $24.12^{\mathrm{b}}$ & $26.47^{\mathrm{ab}}$ & $25.60^{\mathrm{ab}}$ & $26.31^{\mathrm{ab}}$ & $25.48^{\mathrm{b}}$ \\
& \pm 0.69 & \pm 1.80 & \pm 1.02 & \pm 0.81 & \pm 0.98 & \pm 1.14 & \pm 1.12 & \pm 1.69 \\
HSI\% & & $2.64^{\mathrm{a}}$ & $2.89^{\mathrm{a}}$ & $2.34^{\mathrm{a}}$ & $2.16^{\mathrm{a}}$ & $2.79^{\mathrm{a}}$ & $2.44^{\mathrm{a}}$ & $2.68^{\mathrm{a}}$ \\
& - & \pm 0.44 & \pm 0.43 & \pm 0.51 & \pm 0.15 & \pm 0.46 & \pm 0.53 & \pm 0.37 \\
Energy (Kcal GE/fish) & $0.52^{\mathrm{d}}$ & $18.69^{\mathrm{ab}}$ & $19.76^{\mathrm{a}}$ & $15.07^{\mathrm{bc}}$ & $14.36^{\mathrm{bc}}$ & $14.72^{\mathrm{bc}}$ & $13.97^{\mathrm{c}}$ & $14.95^{\mathrm{bc}}$ \\
& \pm 0.017 & \pm 2.42 & \pm 0.91 & \pm 1.41 & \pm 1.82 & \pm 1.18 & \pm 1.04 & \pm 0.82 \\
\hline \multicolumn{2}{c}{ Means having the same letter in the same row are not significantly differed atP>0.05 } & & &
\end{tabular}

Means having the same letter in the same row are not significantly differed at $P>0.05$.

\section{Second study: Digestibility trial:}

Averages of nutrient digestibility using crude fiber as indicator for dry matter (DM), crude protein (CP), ether extract (EE), Ash, nitrogen free extract (NFE) and energy, are presented in Table (9). Firstly, DM digestibility $(\%)$ results revealed that the highest DM digestibility coefficient $(\mathrm{P}<0.05)$ was recorded by the control diet (91.94) and the lowest value was recorded by 100\% MBS (86.06) with significant differences $(\mathrm{P}<0.05)$ among treatments. Secondly, $\mathrm{CP}$ digestibility coefficient group fed on the diet containing 15\% MBS had the highest value $(73.37)$ and the lowest value $(\mathrm{P}<0.05)$ was recorded by the 
diet containing $100 \%$ MBS (57.72) with significant differences $(\mathrm{P}<0.05)$ among treatments. Thirdly, results cleared that the control and 15\% MBS groups had the highest significant $(\mathrm{P}<0.05)$ of EE digestibility coefficient ( 84.88 and $83.73 \%$ respectively) followed by significant decreasing order for the other groups. Fourthly, digestibility coefficient of ash for 45, 60, 75 and 100\% MBS, were significantly $(\mathrm{P}<0.05)$ higher than that of the control, 15 and 30\% MBS groups. Fifthly, the NFE digestibility recorded the highest value recorded to $15 \%$ MBS (90.22) but the $75 \%$ MBS, recorded the lowest one (85.15) without any significant difference $(\mathrm{P}>0.05)$. Finally, the highest value of energy digestibility coefficients was recorded by the $15 \%$ MBS $(85.18 ; \mathrm{P}<0.05)$, but the lowest value recorded by $100 \%$ MBS $(77.19)$. These results may indicate that incorporation $15 \%$ MBS into diets of Nile tilapia resulted in pronounced improvement in digestibility of $\mathrm{CP}, \mathrm{EE}, \mathrm{NFE}$ and energy. These results according with finding of Hossain and Jauncy (1989) revealed that incorporation of sesame seed meal at 25, 50 and $75 \%$ of the dietary protein in common carp diets decreased the apparent digestibility of dry matter, crude protein, lipids and energy compared to the control diet containing $52.50 \%$ fish meal. In general, Mung bean contains anti-nutritional substances such as antitrypsin (Desphande et al., 1982) that hinder the digestibility of certain nutrients. The trypsin inhibitor in mung beans is similar to one of the two trypsin inhibitors found in black-eyed peas but different from that of soybeans (Chrispeels and Baumgartner, 1978). Saleh (2001) showed that DM digestibility coefficient of Nile tilapia ranged between 80.04 to 95.09\% using fibers as internal marker. Also, CP digestibility coefficient of 60.30 to $85.53 \%$ (crude fiber method), and digestibility coefficient of EE and NFE obtained in the present study are almost matching with those reported by the same author and differences may due to the differences in the ingredients tested.

Table (9): Apparent nutrient digestibility coefficient (ADC \%) of the experimental diets by using crude fiber as internal digestive indicator for fry Nile tilapia (O. niloticus).

\begin{tabular}{lcccccc}
\hline \multirow{2}{*}{$\begin{array}{l}\text { Treatme } \\
\text { nts }\end{array}$} & DM & CP & EE & Ash & NFE & Energy \\
\cline { 2 - 6 } Control & $91.94^{\mathrm{a}}$ & $70.69^{\mathrm{a}}$ & $83.73^{\mathrm{a}}$ & $42.79^{\mathrm{ab}}$ & $90.21^{\mathrm{a}}$ & $84.66^{\mathrm{ab}}$ \\
& \pm 2.05 & \pm 2.18 & \pm 6.97 & \pm 1.90 & \pm 2.16 & \pm 1.37 \\
$15 \%$ & $90.67^{\mathrm{ab}}$ & $73.37^{\mathrm{a}}$ & $84.88^{\mathrm{a}}$ & $32.79^{\mathrm{b}}$ & $90.22^{\mathrm{a}}$ & $85.18^{\mathrm{a}}$ \\
& \pm 0.74 & \pm 2.99 & \pm 2.70 & \pm 9.81 & \pm 1.06 & \pm 1.13 \\
$30 \%$ & $89.03^{\mathrm{abc}}$ & $73.31^{\mathrm{a}}$ & $80.16^{\mathrm{ab}}$ & $43.33^{\mathrm{ab}}$ & $89.93^{\mathrm{a}}$ & $84.13^{\mathrm{ab}}$ \\
& \pm 0.29 & \pm 0.99 & \pm 4.05 & \pm 9.57 & \pm 0.43 & \pm 0.62 \\
$45 \%$ & $87.41^{\mathrm{bc}}$ & $67.83^{\mathrm{ab}}$ & $61.15^{\mathrm{b}}$ & $59.41^{\mathrm{a}}$ & $88.66^{\mathrm{a}}$ & $80.62^{\mathrm{abc}}$ \\
& \pm 1.80 & \pm 5.38 & \pm 6.88 & \pm 2.37 & \pm 1.63 & \pm 2.96 \\
$60 \%$ & $86.93^{\mathrm{bc}}$ & $59.46^{\mathrm{b}}$ & $61.97^{\mathrm{b}}$ & $57.67^{\mathrm{a}}$ & $85.46^{\mathrm{a}}$ & $80.14^{\mathrm{bc}}$ \\
& \pm 0.59 & \pm 1.87 & \pm 7.90 & \pm 2.16 & \pm 1.48 & \pm 1.43 \\
$75 \%$ & $86.93^{\mathrm{bc}}$ & $57.78^{\mathrm{b}}$ & $61.50^{\mathrm{b}}$ & $59.20^{\mathrm{a}}$ & $85.15^{\mathrm{a}}$ & $79.94^{\mathrm{bc}}$ \\
& \pm 0.53 & \pm 4.75 & \pm 10.00 & \pm 2.59 & \pm 1.67 & \pm 0.96 \\
$100 \%$ & $86.06^{\mathrm{c}}$ & $57.72^{\mathrm{b}}$ & $61.52^{\mathrm{b}}$ & $59.13^{\mathrm{a}}$ & $85.30^{\mathrm{a}}$ & $77.19^{\mathrm{c}}$ \\
& \pm 1.62 & \pm 3.30 & \pm 4.22 & \pm 6.19 & \pm 1.42 & \pm 0.57 \\
\hline
\end{tabular}

Means having the same letter in the same row are not significantly differed at $P>0.05$.

\section{CONCLUSION:}

To put it in a nut shell, with any adverse effect on Nile tilapia growth performance, feed utilization and apparent nutrient digestibility coefficient (ADC \%), the MBS -as a source of protein- can be replaced (with a rate of $\geq 15 \%$ ) with the soybean meal diets. But conversely, increasing the replacement $\%$ the anti-nutritional factors (phytic acid, saponin and polyphenol contents) will affect negatively on the performance. These results are similar with that obtained by Ganzon-Naret (2013) who reported, conversely, that $18-20 \%$ replacement of fish meal by mung bean protein negatively affected the growth, FCR, and PER, of sea bass So, the raw leguminous plant protein source must be treated (processing and cooking methods including soaking, ordinary and pressure cooking of soaked and unsoaked seeds, and sprouting, where, they significantly decreased phytic acid, saponin, polyphenol enzyme inhibitors, and lectins contents of the amphidiploid seeds (Kataria et al., 1989). In another study Apines-Amar et al. (2015) reported that overall, mung bean is a promising protein source for milkfish and can be included 
up to $20 \%$ of the diet contributing as much as $17 \%$ of the total dietary protein without detrimental effects on growth, feed performance, PER, protein retention, HSI, and liver and intestinal histology. However, the economic evaluation of MBS as replacement for soybean meal in feed for the different aquaculture species needs further studies. Lastly, the sensory qualities of the aquaculture products derived from fish fed diets with MBS should also be tested to ensure quality food fish that are acceptable to consumers.

\section{REFERENCES}

Abd El-Hakim, N.F., A.A, Al-Azab and A.A. El-Kholy (2003). Effect of feeding some full fat oil seed on performance of tilapia hybrid $(O$. niloticus $\times O$. aureus) reared in tanks. Egyptian J. Nutrition and Feeds, 6 (Special Issue): 389-403.

Abd El-Hakim, N.F., M.E. Lashin, A.A. Al-Azab and H.M. Nazmi (2008). Effect of replacing soybean meal with other plant protein source on protein and energy utilization and carcass composition of Nile tilapia (O. niloticus). The $8^{\text {th }}$ International Symposium on Tilapia Aquaculture, Cairo, Egypt pp: 979-997.

Abd El-Hamid, A.M., M.F.I. Salem and A.E. Tolan (2004). Evaluation of sesame meal as a dietary protein source for Nile Tilapia (O. niloticus) fingerlings. J. Agric. Sci. Mansoura Univ., 29: 6887-6897.

Abd El-Hamid, A.M., M.F.I. Salem and M.M. Khalafalla (2006). Substitution of soybean meal by water hyacinth hay in diet of Nile Tilapia. The $2^{\text {nd }}$ International Scientific Congress for Environment, Recent Environmental Problems and Starement, 28-30 March, South Valley University, PP: 114125 .

Adebayo, O.T., O.A. Fagbenro and T. Jegede (2004). Evaluation of Cassia fistula meal as a replacement for soybean meal in practical diets of Oreochromis niloticus fingerlings. Aquaculture Nutrition, 10: 99-104.

Ahmed, M.H., F.E Abbass and M.E.A Seden (2009). The effect of partial replacement of soybean meal by black seed meal in practical diet on growth performance, feed utilization and whole body composition of Nile tilapia, O. niloticus (L). Fingerlings. Abbassa Int. J. Aquacultur (1): 99-114.

Akiyama, D., S.R. Coelho, A.L. Lawrence and E.H. Robinson (1989). Apparent digestibility of feedstuffs by the marine shrimp, Penaeus vannamei Boone. Nippon Suisan Gakkaishi, 55: 9198.

Alcerte, C. (2000). Tilapia alternative protein sources in tilapia feed formulation Aqua. May. Online Jul/Aug 26 (4).Apines-Amar, M.J.S., M.C. Relicardo, M.N.G. Amar, M.S.M. Golez, G.B.B. Marj and J.J. Cecilia (2015). Utilization of Mung Bean, Vigna radiata (Linnaeus) as a Novel Protein Source in Practical-Type Diets for Juvenile Milkfish, Chanos chanos (Forsskal): Effects on Growth, Feed Efficiency, Body Composition, and Histology of Gut and Liver. The Israeli Journal of Aquaculture - Bamidgeh, IJA_67.2015.1237, 10 pages

AOAC (1990). Official Methods of Analysis. Association of official analytical chemsts. Washington, D.C.

AOAC (2005). Official methods of analysis, 18th .Ed. Vol. 1, published by the A.O.A.C., Benjamin Francklin station, Washington, DC.

Azaza, M.S., K. Wassim, F. Mensi, A. Abdelmouleh, B. Brini and M.M. Kraïem (2009). Evaluation of faba beans (Vicia faba L. var. minuta) as a replacement for soybean meal in practical diets of juvenile Nile tilapia O.niloticus. Aquaculture, 287: 174-179.

Chrispeels M.J. and B. Baumgartner (1978). Trypsin inhibitor in mung bean cotyledons. Purification, characteristics, subcellular localization, and metabolism. Plant Physiol., 61: 617-623.

De Silva, S.S and T.A. Anderson (1995). Fish Nutr Aquacult., Chapman \& Hall, London. 320pp. 
Desphande S.S., S.K. Sathe, D.K. Salunkhe and D. Cornforth (1982). Effects of dehulling in phytic acid, polyphenols and enzyme inhibitors of dry bean (Phaseolus vulgaris L.). J. Food Sci., 47:18461849.

Duncan, D.B. (1955). Multiple range and multiple F tests .Biometrics, 11;1-42.

El Sherbiny, M.A. (2008). Use of non-conventional feed sources in Nile tilapia diets. PhD. Thesis, Animal Production Department, Faculty of Agriculture. Cairo Univ. Cairo, Egypt. 187pp.

El-Adawy, T.A. (1996). Chemical, nutritional and functional properties of mungbean protein isolate and concentrate. Minufiya J. Agric. Res., 21(3):657-672.

El-Sayed, A.F.M. (1999). Alternative dietary protein sources for farmed tilapia, Oreochromis spp. Aquaculture, 179:149-168.

Eusebio, P.S. and R.M. Coloso (2000): Nutritional evaluation various plant protein sources in diets for Asian sea bass lates calcarifer. Journal of Agriculture and Food Chemistry, 15: 439-443.

Francis, G., H.P.S. Makkarm and K. Becker (2001): Anti-nutritional factors present in plant-derived alternate fish feed ingredients and their effects in fish. Aquaculture, 199: 197-227.

Ganzon-Naret, E.S. (2013). The potential use of legume-based diets supplemented with microbial phytase on the growth performance and feed efficiency of sea bass, Lates calcarifer. AACL Bioflux, 6(5):453-463.

Habibullah, A.M. and H.U. Shah (2007). Proximate and mineral composition of mung beans. Sarhad J. Agric., 23(2):463-466.

Hossain, M.A. and K. Jauncey (1989): Nutritional evaluation of some Bangladeshi oilseed meal as partial substitute for fish meal in the diets of common carp, Cyprinus carpio L. Aquacult. Fish Manage., 20: 255-268.

James, M.B., O.O. Elijah, C.N. Charles, M.L. David, R. Joseph, V. Chepkirui-Boit, M. Opiyo and N. James (2015). Utilization of Caridina nilotica (Roux) meal as a protein ingredient in feeds for Nile tilapia (Oreochromis niloticus). Aquaculture Research, 46: 346-357

Jones, P.L. and S.S. De Selva (1998). Comparison of internal and external markers in digestibility studies involving the Australian fresh water Crayfish, Cherax destructor Clark (Decapoda, Parastacidae). Aquaculture, 29:487-493.

Kataria, A., B.M. Chauhan and D. Punia (1989). Anti-nutrients in amphidiploids (black gram x Mung bean): varietal differences and effect of domestic processing and cooking. Plant Foods for Human Nutrition, 39: 257-266.

Kenawi, A.M., R.R. Abdelsalam and A.S. El-Sherif (2009). Effect of mung bean powder, and/or low fat soy flour as meat extenders on the chemical, physical and sensory quality of buffalo meat product. Biotechnology in Animal Husbandry, 25:327- 337.

Kirchgessner, M., H Kurzinger and F.J Schwarz (1986). Digestibility of crude nutrients in the different feeds and estimation of their energy content for carp (Cyprinuscarpio L.). Aquaculture, 58:185194.

Lee, P.G. and A.L. Lawrence (1985). Effects of diet and size on growth, feed digestibility and digestive enzyme activities of the marine shrimp, Penaeus setiferus Linnaeus. J. World Maricult. Soc., 16:275-287.

Liener, I.E. (1989). Anti-nutritional factors in legume seeds: State of the Art. In: Huisman, J., Van der poel, A.F.B., Liener, I.E. (Eds.), Recent Advances of Research in Antionutritional Factors in Legume Seeds. Pudoc, Wageningen, pp. 6-14. Cited by Francis et al, (2001).

Lovell, R.T. (1988). Use of soybean products in diets for aquaculture species. J. Aquat. Prod. 2:27-52.

Magouz, F.I., M.O El-Gendi, M.F.I. Salem and A.A. El-Azal (2008). Use of cucumber, squash and broad bean leaves as non-conventional plant protein source in Nile tilapia $(O$. niloticus $)$ diet. The $8^{\text {th }}$ international symposium on Tilapia Aquaculture. pp: 847-759. 
Mohammed, A.A.E. (2008). Use of non-conventional feed sources in Nile tilapia diets. Ph. D. Thesis, Fac. Agric., Cairo Univ.

Mubarak, A.E. (2005). Nutritional composition and anti-nutritional factors of mung bean seeds Phaseolous aureus as affected by some home traditional processes. Food Chemistary., 89 (4): 489-495.

Norton, G. (1991). Proteinase inhibitors. In D'Mello, F.J.P., Duffus, C.M., Duffus, J.H. (Eds.), Toxic substances in crop plants. The Royal Society of Chemistry, Thomas Graham House, Science Park, Cambridge CB4 4WF, Cambridge, pp 68-106.

NRC (1993). Nutrient requirements of fish. Committee on. Animal Nutrition. Board on Agriculture. National Research Council. National Academy Press. Washington DC., USA. pp. 114.

Olaifia, F.E. and O.S. Bello (2011). Effect of Differently Processed African Yam Beans (Sphenostylis stenocarpa Harms) on Performance of African Catfish (Clarias gariepinus) Juveniles, 7 pages. Isr. J. Aquacult. - Bamidgeh, 595, 7 pages.

Rahman-tibin, M.E.A., A.B. Abol-Munafi, A.M. Amiza, B.H. Khoda and S.H.M. Adam (2012). Apparent digestibilty coefficient of pelleted fish feed incorporated with water hyacinth (Echhornia crassipes). Online Journal of Animal and Feed Research, 1:30-33.

Ramakrishna, V., P. Jhansi Rani and R.P. Ramakrishna (2006). Anti-nutrition factors during germination in India bean Dolichos lablab L. seeds. World Journal of Diary and Food sciences., 1(1): 6-11.

Saleh, H.D.T. (2001). The use of non-conventional energy and protein feed sources in Nile tilapia diets. $\mathrm{Ph}$. D. Thesis Animal Production Department, Fculty of Agriculture, Cairo Unversity.

Sales, J. and G.P.J. Janssens (2006). A not on ash as indigestible dietary marker to determine digestibility of seeds in adult granivourous birds. J. Anim. Feed Sci. 12:97-102.

Sidduraju, P. and K. Becker (2001). Preliminary nutritional evaluation of mucuna seed meal (Mисuna pruriens. Var. Utilis) in common carp (Cyprinus carpio L.): an assessment by growth performance and feed utilization. Aquaculture., 196:105-123.

SPSS, (Software Program of Statistical Analysis) (2001). Data Analysis for the Behavioral Sciences. SPSS Inc., Prentice, Hall, USA.

Storebakken, T., S. Refstie and B. Ruyter (2000). Soy products as fat and protein sources in fish feeds for intensive aquaculture. In: Drackly, J.K. (Ed.), Soy in Animal Nutrition. Federation of Animal Science Societies, Savoy, IL, pp. 127-170.

Wheeler, E.L. and R.E. Ferrel (1971). A method for phytic acid profiles through the digestive tract of Lumbricus terresris L. Applied Soil Ecology., 35(1): 226-236. 


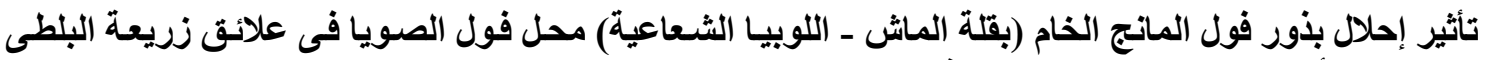
النيلى على أداء النمو والاستفادة من الغذاء ومعامل الهضم الظاهرى الثاءئ

\author{
1مصطفى أحمد محم سليمان، 2أحمد مصطفى بطران، 3حمدى احمد لحمل سليمان، 2صفوت عبد الغنى عبد المجيد جمعه

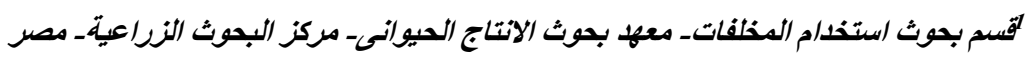

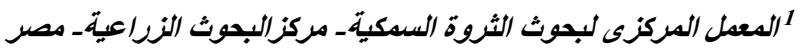

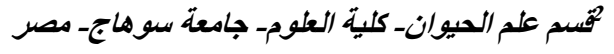

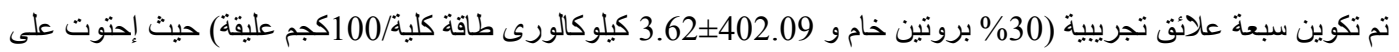

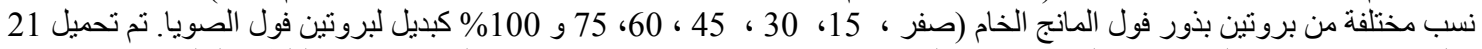

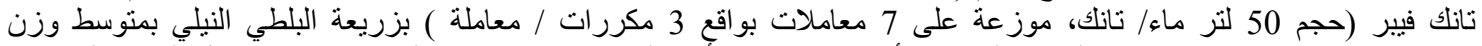

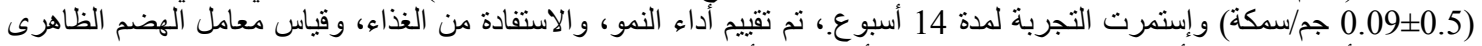

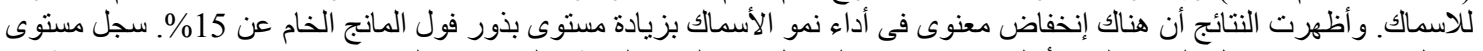

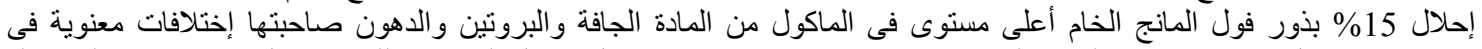

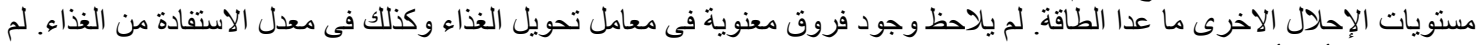

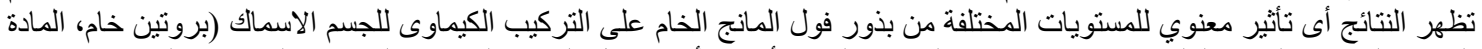

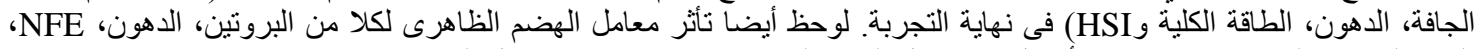

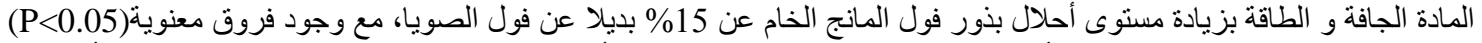

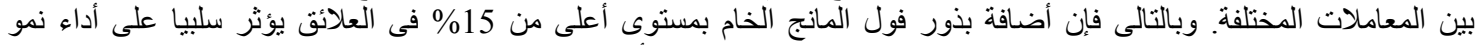

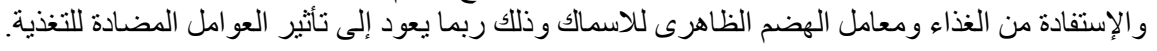

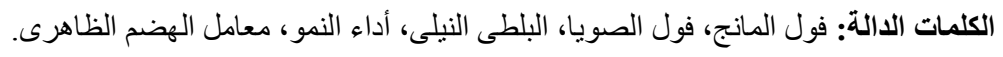

